\title{
The International Law of Secession and the Protection of the Human Rights of Oppressed Sub-State Groups: Yesterday, Today and Tomorrow
}

Obiora C. Okafor

Osgoode Hall Law School of York University, ookafor@osgoode.yorku.ca

\section{Source Publication:}

1 Nigerian Yearbook of International Law

Follow this and additional works at: https://digitalcommons.osgoode.yorku.ca/scholarly_works

Part of the International Law Commons

\section{Repository Citation}

Okafor, Obiora C., "The International Law of Secession and the Protection of the Human Rights of Oppressed Sub-State Groups: Yesterday, Today and Tomorrow" (2017). Articles \& Book Chapters. 2645. https://digitalcommons.osgoode.yorku.ca/scholarly_works/2645 


\title{
The International Law of Secession and the Protection of the Human Rights of Oppressed Sub-State Groups: Yesterday, Today and Tomorrow
}

\author{
By \\ Obiora Chinedu Okafor ${ }^{*}$
}

\section{Introduction:}

This paper focuses on significant patterns/features in the historical development of the international law of secession and its contribution over time (or the lack thereof) to the struggle to afford greater protection to oppressed sub-state groups the world over. It was Crawford Young who once observed that "the state as an analytical quarry is an elusive and complex prey." ${ }^{1}$ With the necessary modifications, this observation applies with almost equal force to the international law of secession. Complexity and confusion loom too large in this area of international law. For example, there is, at best, little clarity in the literature of the discipline of international law and in related fields of study regarding the existence or otherwise of an international legal entitlement to secession in favor of even the most highly oppressed and subjugated sub-state groups. ${ }^{2}$

\footnotetext{
* Chairperson, United Nations Human Rights Council Advisory Committee, Geneva, Switzerland; University Research Chair in International and Transnational Legal Studies at the Osgoode Hall Law School, York University, Toronto, Canada; and most recently the Gani Fawehinmi Distinguished Chair in Human Rights Law at the Nigerian Institute of Advanced Legal Studies, Abuja, Nigeria. Ph.D, LL.M (University of British Columbia, Vancouver, Canada); LL.M, LL.B (Hons) (University of Nigeria, Enugu Campus, Nigeria). EMAIL: ookafor@yorku.ca. I am grateful to John Mastrangelo, JD student at the Osgoode Hall Law School for his extraordinarily able research assistance. I specially dedicate this paper to my ever patient and loving family (Atugonza, Ojiako, Mbabazi and Kosi), without whose solid and unflinching support this paper would not have seen the light of day. I should also thank the University of Wisconsin-Madison, especially Professor Sumudu Attapatu, for the invitation to present this paper at that institution as the 2015 Mildred Fish-Harnack Lecture on Human Rights and Democracy. Parts of this paper have been influenced and shaped by my previous work on the international law of statehood. For example: Okafor, Re-Defining (n 2) and Okafor, "Entitlement” (n 2).

${ }^{1}$ Crawford Young, The African Colonial State in Comparative Perspective (Yale University Press 1994) 13.

${ }^{2}$ For examples of the range of opinion in the relevant literature, see: James Crawford, The Creation of States in International Law (Clarendon Press 1979); Thomas M Franck, Fairness in International Law and Institutions (Clarendon Press 1995); Obiora Chinedu Okafor, Re-Defining Legitimate Statehood: International Law and State Fragmentation in Africa (Martinus Nijhoff 2000); Obiora Chinedu Okafor, "Entitlement, Process and Legitimacy in the International Law of Secession" (2002) 9 Intl J on Minority and Group Rights 41; Hurst Hannum, "Rethinking Self-Determination” (1993) 34 Va J Intl L 1; John Dugard, "Secession: Is the Case of Yugoslavia a Precedent for Africa (1992) 5 Afr J Intl Comp L 163; Gregory H Fox, "Self-Determination in the Post-Cold War Era: A New Internal Focus” (1995) 16 Mich J Intl L 733; J Oloka-Onyango, "Heretical Reflections on the Right to Self-Determination: Prospects and Problems for a Democratic Global Future in the New Millenium” (1999) 15 Am U Intl L R 151; Antonio Cassese, Self-Determination of Peoples: A Reappraisal (Cambridge University Press 1995); Ian Brownlie, Principles of Public International Law (Clarendon Press 1990); Fredric L Kirgis Jr, "The Degrees of SelfDetermination in the United Nations Era” (1994) 88:2 AJIL 304; Robert McCorquodale, "SelfDetermination Beyond the Colonial Context and its Potential Impact on Africa" (1992) 4 Afr J Intl Comp L 592; Stephen J Toope, "Re Reference by Governor in Council Concerning Certain Questions Relating to Secession of Quebec from Canada" (1999) 93 AJIL 519; and Thomas M Franck, "Post-Modern Tribalism and the Right to Secession” in Catherine Brolman, Rene Lefeber, and Marjoleine Zieck (eds), Peoples and Minorities in International Law (Martinus Nijhoff 1993).
} 
Given this unsatisfactory state of the literature on a subject of such great importance not only to the stability of the Westphalian state system, but also to the human rights, lives and even the very survival of the multitudes of subaltern sub-state groups who suffer under highly oppressive state formations across the globe, it is meet that yet another systematic look be taken at "the state of the art" on this aspect of "the art of the state." 3 This is what this paper attempts to do, albeit only by way of providing a bird's eye view of the relevant international socio-legal terrain. The paper analyzes the relevant international legal texts and practices with a view to deciphering broad patterns in the historical development of the international law of secession; especially with regard to understanding its historic (in)capacity to serve as a normative resource in the hands of those who have struggled for the liberation of all-too-many oppressed "peoples" from their parent states.

The substantive arguments of the paper are developed in its three main sections; which are collectively sandwiched by an introduction and a conclusion. The substantive analysis conducted in the main sections of the paper is organized in a historical way, in the sense that the state of affairs in the area of the international law of secession in the era before the current period (what is referred to in this paper as "yesterday") is discussed in section II of the paper, and that this is done as a background to the analysis provided in section III on the position of that legal regime over the last four decades or so (what we have styled "today"). Following these discussions, section IV is then devoted an analytical projection into the future of the international law of secession (i.e. into its "tomorrow"). Section V concludes the paper.

\section{Yesterday:}

In the century or so before the UN era (i.e. in the epoch before the adoption of the UN Charter, the two principal international human rights covenants, and the so-called Declaration on Friendly Relations ${ }^{4}$ ), the international law on the secession of sub-state groups from already established states was more or less characterized by the following features/attitudes: little - if any - treaty or negotiated soft law norms; the near-total dominance of customary international law norms; the almost total dominance of the doctrine that effectiveness confers legitimacy; little - if any - human rights discourse or its application; little - if any - adjudicative or even democratic political process; a very strong tendency among states to selectively invoke pro- or anti-secession principles; a concept of legitimate statehood that tended to accept and reflect social power/injustice rather than tackle or resist it; and a consequent normative orientation that severely disadvantaged, if not repressed, all too many of the discrete "peoples" that together constituted the established states of that era. Each of these broad patterns will now be discussed one after the other.

\section{Little - if any - treaties or negotiated soft law norms}

\footnotetext{
${ }^{3}$ Friedrich Kratochwil and John Gerard Ruggie, "International Organization: A State of the Art on an Art of the State” (1986) 40 Intl Org 753.

${ }^{4}$ Charter of the United Nations, 26 June 1945, 3 Bevans 1153; the International Covenant on Economic, Social and Cultural Rights, (1967) 6 ILM 368; International Covenant on Civil and Political Rights, (1967) 6 ILM 368; Declaration on Principles of International Law concerning Friendly Relations and Cooperation among States in accordance with the Charter of the United Nations (24 October 1970) UNGA Res A/RES/25/2625.
} 
An important feature of the international law of secession in this pre-UN period, in yesterday's era, was the almost total absence of global or even regional level treaty law on the subject. The field was almost completely dominated by customary international norms, many of which were and remain of uncertain meaning and scope. As between custom and treaties, the latter had the potential of much more rapidly transforming the law in this area in a much more progressive human rights-centered direction. Given the manner in which custom develops and emerges in international law, a similar customary international law process would have of necessity been much slower and more fraught with uncertainty and confusion. The fact remains, however, that it was in custom and not treaty international law that the traditional international law of secession was to be found.

\section{Near-total dominance of the effectiveness doctrine}

Regarding the near total dominance in the traditional international law of secession of the doctrine that effectiveness confers legitimacy, it is best to begin by explaining - albeit in brief - the meaning and essence of this doctrine. As ably re-stated by James Crawford, the doctrine asserts that where a state actually exists, the law must take favorable account of the new situation despite its illegality or illegitimacy, and where a state does not in fact exist, norms or rules requiring that it exist can only be pointless, a denial of reality. ${ }^{5}$ And so when once an act of state formation or secession has been effectively done, it is lawful and legitimate precisely because it is effective. ${ }^{6}$ And so for sub-state groups that were part of established (non-colonial) states, the path to liberation from oppressive state formations was in this era almost exclusively violent. ${ }^{7}$ For, rarely would or did an established state look favorably on the secessionist agitations of such groups - and this was so regardless of the extent of the oppression visited on the relevant sub-state group by the state at issue. ${ }^{8}$ This meant that such groups were almost invariably forced to take up arms against their parent states if they were to have any chance at all of liberating themselves from such oppression by seceding from these states. ${ }^{9}$ If their effort was successful, they benefited from the doctrine that effectiveness confers legitimacy, but if they failed, the near-total dominance of the effectiveness doctrine in the era under review meant that the normative legitimacy of their struggle to be free the violation of their human rights by their states counted for very little, if anything at all in traditional international law.

\section{A politics with little rights}

This point leads to quite logically to another characteristic of the international law of secession in the pre-UN era: the fact that during this period the international politics of

\footnotetext{
${ }^{5}$ Crawford (n 2).

${ }^{6}$ ibid.

${ }^{7}$ Okafor, Re-Defining (n 2) 92-125.

${ }^{8}$ ibid.

${ }^{9}$ ibid. For example, during this pre-1945 era, the legitimacy or otherwise of the creation or (re)emergence of a new state from another one was almost entirely a matter of the political/military effectiveness of that emergent entity, as is witnessed for example by the forcible separation of many states (such as Albania, Serbia, Romani and Montenegro) from the Ottoman Empire during the late $19^{\text {th }}$ and early $20^{\text {th }}$ centuries. See Richard Hall, The Balkan Wars (London: Routledge, 2000); and CIA, World Fact Book: Albania, online: https://www.cia.gov/library/publications/resources/the-world-factbook/geos/al.html (visited 3/12/2015).
} 
state formation and sub-state group secession was - more or less - a politics with little rights, and a high politics that was almost totally devoid of normative constraint. Thus, during this period, a people could suffer from, or be threatened by genocide, mass murder, apartheid, crimes against humanity, or the like, and yet, if they were not actually effective in militarily battling their way out of the control of the relevant state, they could not in almost all cases protect themselves from such grave threats by seceding from the impugned state. Indeed, the very question of their entitlement or right to secede from such deadly or highly oppressive circumstances was a virtually irrelevant one in the traditional international legal order. According to many scholars, the position under the traditional international law of the time was, at best, that the law neither favored not outlawed secession; ${ }^{10}$ a normative position that still reeks of the injustice of Anatole Frances' law that would "equally" prevent the rich and the poor from sleeping under bridges! Yet more accurately, the position in this epoch was that the application of the norm of self-determination to established (non-colonial) states was generally disfavored if it was expected to lead to the break-up of the relevant state. ${ }^{11}$ Thus, in the pre-UN era, the regulation of secession - if it is even possible to refer to it as such - was essentially a function of the play of a form of high international politics that was deeply connected to and almost automatically reflective of the developments on the ground and which identified very closely and heavily with the those who held actual power in the relevant country. Accordingly, it was almost entirely devoid of the kinds of normative considerations and constraints which ought to arise from the demands of human rights in the circumstances.

\section{Little - if any - democratic or adjudicative process}

Not surprisingly therefore, the international law of secession of this era was also almost entirely unconstrained by democratic, what more adjudicative, process. As we have seen, far from establishing a democratic process which took account of the wishes of the oppressed and/or aggrieved peoples who desired to secede from the parent state, traditional international law in fact did the exact opposite. By insisting on the "effectiveness confers legitimacy" doctrine, it explicitly and in effect legitimized a usually violent process of secession, one that recognized new states that had been formed by militarily successful sub-state groups who had rebelled against their parent states, but tended to de-legitimize the militarily unsuccessful attempts to secede of even those substate groups whose bid for secession was justifiably grounded in the egregious and massive violation of their human rights by the relevant state. ${ }^{12}$

What is more, in this era, when the legitimacy of a secessionist bid was assessed under traditional international law, it was not the "infra-review" (i.e. self-assessment) of the members of the relevant sub-state group that counted. ${ }^{13}$ It was rather the "peer review" of the established states in the international community that almost invariably determined whether or not the secessionist bid was considered legitimate or otherwise under traditional international law. ${ }^{14}$ Against this background, it is easy to appreciate why

\footnotetext{
${ }^{10}$ For example: Franck, “Postmodern Secession” (n 2) 159; Hannum (n 2) 42; and Dugard (n 2 ) 165.

${ }^{11}$ Fox (n 2).

12 Okafor, Re-Defining (n 2) 104-106.

13 ibid 54-65, 109-111.

14 ibid.
} 
the notion of a process of third party adjudicative review of the legality and legitimacy of a secessionist bid by a sub-state group was almost completely absent in the living international law of yesterday's era. ${ }^{15}$ As remarkably, this absence or gap was not inconsequential for the protection of the human rights of sub-state groups around the world. The reality that it was success on the battlefield that tended to confer legitimacy on a new secessionist state and the absence of third party adjudicative fora of the triadic type that would have been widely considered legitimate by all sides to the secessionist disputes of that era, together contributed very significantly to the generation and augmentation of high levels of intra-state (and even inter-state) violence the world over. The signal that was sent to restive sub-state groups was in effect: "seek ye the kingdom of war and all other things shall be added unto you.” And apart from being a human rights violation in itself, the ensuing violence all-too-often led in turn to massive violations of the human rights of the affected sub-state groups.

An excessively high level of unjustifiable selectivity

As importantly, this pre-UN era witnessed a very strong tendency among states to selectively invoke pro- or anti-secession principles. This is connected to the points that have already been made about the traditional international law of secession being governed by the effectiveness confers legitimacy doctrine, having been characterized by a politics with little rights, and being generally lacking of a democratic, what more adjudicative, process by which the merits/legality/legitimacy (or otherwise) of secessionist bids were to be evaluated. Without the significant (albeit limited) constraints of normative legitimism, with high politics almost completely displacing human rights standards, and without the benefit of democratic or adjudicative process, little in this era stood in the way of gross selectivity and inconsistency in the application of the principles of international law in this area. For example, in the late $19^{\text {th }}$ and early $20^{\text {th }}$ centuries, the then existing European states supported or opposed the emergence of Albania, Serbia, Romania, Montenegro, and so on, from the Ottoman Empire depending very much on their alignments in regard to the Balkan and other wars of that era.

\section{A largely oppressive concept of legitimate statehood}

As interestingly, and not surprisingly, the dominant conception of legitimate statehood in this pre-UN epoch was basically pro-status quo and tended to uncritically accept and reflect social-political power/injustice rather than tackle or resist it. The interests of established states, no matter how oppressive they were to one or more of the sub-state groups which constituted them tended to dominate over the well-being and even the every survival of the relevant oppressed peoples. As such, in this era, doctrines/principles, such as those on the maintenance of the territorial integrity of states and uti possidetis, almost completely displaced any considerations as to the need to protect sub-state groups from grave and/or systematic violations of their human rights. ${ }^{16}$

The consequent production of severe disadvantage for oppressed sub-state groups Needless to say, therefore, the consequent normative orientation of the traditional international law of this period was one that severely disadvantaged, if not repressed, all

\footnotetext{
${ }^{15}$ Okafor, “Entitlement” (n 2) 56-70.

${ }^{16}$ ibid 72.
} 
too many of the discrete "peoples" that together constituted the established states of that era. The international law of secession of this era clearly placed subaltern peoples at far more disadvantage than established states. The signal that it sent to established states was that they could repress their sub-state groups as much as they wanted, and as long as they were effective in maintaining their power over their territory and citizens, international law and praxis would almost never de-legitimize or de-legalize their statehood. This in turn signaled to the relevant sub-state groups that they should either endure the repression or take up arms and rid themselves of the control that their state exerted over them. In either case, trouble loomed for the oppressed peoples. For the human rights of their members would almost invariably be grossly abused whichever way they chose to act. Remarkably, this tendency to place sub-state groups at a significant disadvantage was in general - not moderated in any way in traditional international law even when the relevant sub-state group had suffered egregious violations of their human rights.

\section{Today:}

It is important to begin by noting that a longer view of "today" is taken here - one that begins a relatively long time ago and stretches into the very present. And so the today that is referred to here began in 1945 when the UN was born following the devastation of what is popularly referred to as World War II, and ends in our own present.

In the current post-1945 UN era (partly characterized as it has been by the adoption of the UN Charter in1945, the operation of the law established by that Charter, the adoption of the two major international human rights covenants in 1966, the coming into force of the latter treaties in 1976, and the adoption by a strong and widespread consensus of the Declaration on Friendly Relations in $1970^{17}$ ), the international law of secession has altered quite significantly in the opposite direction from its traditional orientation and trajectory. And so, while a lot of progress remains if this regime is to ever become sufficiently transformed into a regime that would be much more protective of the human rights of sub-state groups, appreciable progress has nevertheless been made. The challenge is to map the changes that have occurred as accurately as possible and account for them as precisely as we can. Careful analysis of the available material suggests that the international law of secession today is characterized by: significantly more treaty and negotiated soft law norms than was previously the case; a concomitantly diminished role for customary international law norms; a waning of the dominance of the doctrine that effectiveness confers legitimacy; considerably more human rights discourse and its application than was hitherto the case; a greater (if still insufficient) tendency to turn to adjudicative or democratic political process; substantial continuity in the very strong tendency among states to selectively invoke pro- or anti-secession principles; a concept of legitimate statehood that no longer automatically accepts and reflects social power/injustice; and a consequent normative orientation that holds a greater potential to ameliorate the undue disadvantage, if not repression, that has been the historic lot of alltoo-many sub-state groups. These patterns will now be discussed in the order in which they have been outlined here.

\section{A much greater resort to treaties and negotiated soft law instruments}

\footnotetext{
${ }^{17}$ For fuller descriptions of these documents, see note 4 above.
} 
The first two (related) points about the greater role played by treaties and negotiated soft law documents in today's international law of secession, and the consequently lesser space available for customary international law norms to fill in this area, are easily made. The key point here is that before the UN era, the international law of secession was far less governed by treaty negotiated soft law norms than it is today. The UN Charter itself proclaims in Article 1 (purposes) and Article 55 (respect for human rights) that friendly relations among nations, which it desired to become the norm, is to based in part on respect for equal rights and self-determination of peoples, but it did not specify if this principle of self-determination was to be limited to the colonial context. Nevertheless, the broad academic consensus is that the understanding of self-determination at that time was in fact limited to the colonial context. ${ }^{18}$ However, sometime within the long duration of today's era, probably in the 1970s and 1980s, this understanding began to gradually shift toward one that accommodated self-determination in some form or the other in the context of established non-colonial states. ${ }^{19}$ This last point will be explored more fully later on in this section. The point here, however, is that this gradual shift (which is mostly a good thing) was largely due to the emergence of treaty-based and negotiated soft lawbased norms. These include: the common Articles 1 of the International Covenant on Economic, Social and Cultural Rights (hereinafter the ESC Rights Covenant) and the International Covenant on Civil and Political Rights (hereinafter the CP Rights Covenant), and paragraph 7 of the section of the Declaration on Friendly Relations that dealt with the principle of equal rights and self-determination of peoples. It is considered that these developments were a good thing because treaties and negotiated soft law instruments have a much greater potential than custom (which develops very slowly and in fits and starts) to more rapidly and robustly transform the law in this area; hopefully in the more pro-sub-state group way already indicated. Decisions have of course emerged from at least one domestic court, the African regional human rights system, and the International Court of Justice, that have - to varying degrees - fed off and reinforced this trend, but the point remains that the trend was set-off by the emergence of treaty law and the consequent diminishment (however slightly) of the role of customary law in this regard. The relevant cases will be discussed later on in this section of the paper.

The waning of the effectiveness doctrine

The point about today's international law of secession being characterized by the waning of the dominance of the doctrine that effectiveness confers legitimacy is also easy to make. This is so largely because this view is strongly supported in the literature. ${ }^{20}$ While the effectiveness doctrine remains the dominant criterion for the evaluation and acceptance of statehood, it no longer confers legitimacy automatically. ${ }^{21}$ A good example of this diminishment in the power of the effectiveness doctrine in the international law of secession is that as far back as the 1990s European states codified this turn in a soft law document that exhibited great power in real political life in Europe, the Guidelines on the

\footnotetext{
${ }^{18}$ For example: Oloka-Onyango (n 2); Cassese (n 2) 328; Brownlie (n 2); and Kirgis (n 2) 305.

${ }^{19}$ For example: Fox (n 2); McCorquodale (n 2) 593; Toope (n 2); and Franck, "Postmodern Secession” (n 2).

${ }^{20}$ For example: Franck, "Postmodern Secession” (n 2) 7; Nii Lante Wallace-Bruce, Claims to Statehood in International Law (Carlton Press 1994) 67; Crawford (n 2) 77; and Martti Koskenniemi, "The Future of Statehood” (1991) 32 Harv Intl L J 397.

${ }^{21}$ Okafor, Re-Defining (n 2) 67.
} 
Recognition of New States in Eastern Europe and in the Soviet Union. ${ }^{22}$ This document does not even refer to the effectives of the newly seceded candidate states as a basis for their recognition by other European states. ${ }^{23}$ Instead, it contains "a long list of normative requirements to be met by the aspirant states before legitimacy could be conferred on them by their would-be peers." ${ }^{24}$ What is more, as Crawford has correctly noted, since 1945, a significantly large number of separate and independent entities have emerged which have, universally, been agreed not to be states (for example Taiwan, then Rhodesia, Somaliland, and the breakaway regions of Georgia), and moreover, many noneffective entities have also been generally regarded as being, or continuing to be, states (for example Kuwait while under Iraqi occupation, Bosnia under Serbian occupation). ${ }^{25}$ It should be re-emphasized though that the fact that the power of the effectiveness doctrine in this area has waned significantly does not mean that it has completely dissipated. Far from it; for as Milena Sterio has correctly argued, even in contemporary international law, it all-too-often appears as if the right to secession accrues in reality for sub-state groups if and when the great powers decide to support their causes. ${ }^{26}$ The example of the effective secession of Kosovo from Serbia with strong EU, USA, and Western support, can be offered. In this regard, it should be noted that (as we will soon see), although an excellent case can be made that Kosovo, as an exceptional case, was entitled to secede as a remedy for their highly oppressive treatment by Serbia, the decision of the International Court of Justice on the Kosovo secession matter neither supports nor undermines the case made by the representatives of the people of Kosovo for secession from Serbia. The court basically refused to deal with this core question at issue in the case.

\section{A politics with much more rights-based praxis}

It is interesting to note that the major reason for this waning of the effectiveness doctrine in the area of the international law of secession is that a distinct, if incomplete, turn to the application of normative criteria has begun; one that has been largely grounded in the application of human rights standards and a kind of human rights mentality. Before adumbrating on this shift, it should be made clear at the outset that even contemporary international law (be it treaty or custom-based) does not recognize a generalized right to unilateral secession for all sub-state groups simply because they so choose or are uncomfortable within their parent state. ${ }^{27}$ The operation of important norms of international law such as the maintenance of the principle in favor of the territorial integrity of established states has meant that the general norm in international law has dictated that the right to self-determination must, in the vast majority of cases, be enjoyed within the confines of the parent state (for example via local autonomy or self-

\footnotetext{
${ }^{22}$ Guidelines on the Recognition of New States in Eastern Europe and in the Soviet Union, 16 December 1991, reprinted in (1993) 9 Eur J Intl L 46 annex at 72.

${ }^{23}$ Okafor, Re-Defining (n 2) 67.

24 ibid.

${ }^{25}$ Crawford (n 2) 77.

${ }^{26}$ Milena Sterio, “On the Right to External Self-Determination: 'Selfistans', Secession and the Great Powers’ Rule” (2010) 19 Minn J Intl L 137.

${ }^{27}$ Cassese (n 2); Franck, "Post-Modern Tribalism,” (n 2); Dugard (n 2) 165; Christian Tomuschat, "SelfDetermination in a Post-Colonial World" in Christian Tomuschat (ed), Modern Law of Self-Determination (Martinus Nijhoff 1993) 7; and Okafor, “Entitlement” (n 2) 47.
} 
government). ${ }^{28}$ The literature is so crystal clear on this particular point that developing it further need not detain us unduly here. Suffice it to note that the general attitude among states, international institutions, and in the literature, to the existence of such a generalized entitlement remains as hostile as ever. ${ }^{29}$ Indeed, at a January 2007 debate of the Third Committee of the UN General Assembly, on the right to self-determination, almost all the representatives of states present (and there were very many of them) kept silent on the existence or otherwise of the right to secession even as they discussed the right to self-determination in more general terms. ${ }^{30}$ This is emblematic of the marginalization of any form of secession talk among states even within general selfdetermination discourse. ${ }^{31}$ Indeed, India's representative at that debate summed up this dominantly hostile attitude thus: "the right to self-determination could not be abused to encourage secessionism and undermine pluralistic, democratic States...Such a view would only aid the forces of ethnic, religious and racial exclusivity." ${ }^{32}$ Yet, it is important to acknowledge that this dominant hostility to secession is not total. As the representative of Armenia said during the same debate, in part in response to the Indian representative, "many of the current unresolved conflicts [around the world] resulted from the suppression of peoples' aspirations for self-determination.”33

Nevertheless, the far more interesting question today is whether such suppressed peoples, the kind of sub-state groups whose protection is at issue in this paper, now enjoy a narrower, conditional, right or entitlement under treaty and/or customary international law to unilateral secession from parent states which have treated them with a high enough degree of oppression, discrimination, i.e. when there are "exceptional circumstances" or "unique cases"? The argument that is developed here is that they now enjoy this right, in part as a result of the turn to normative (largely human rights-based) criteria in the international law of secession. The first firm indication of the congealing of this limited and conditional right to secession in exceptional cases only, within customary international law, was offered by the decision of the African Commission on Human and Peoples’ Rights in the so-called Katanga case. In that case, the Commission (which was at the time the only authoritative interpreter of the African Charter on Human and Peoples' Rights ${ }^{34}$ ) felt able to boldly declare that:

"In the absence of concrete evidence of violations of human rights to the point that the territorial integrity of Zaire [now the Democratic Republic of the Congo] should be called into question and in the absence of evidence that the people of Katanga are denied the right to participate in government as guaranteed by Article 13(1) of the African Charter, the Commission holds the view that Katanga is obliged to

\footnotetext{
28 Jure Vidmar, Democratic Statehood in International Law: The Emergence of New States in Post-Cold War Practice (Hart 2013) 50, 202-232, 244-245.

${ }^{29}$ Sakina Kabir B and Obinna James Edeh, “An Evaluation of the EU and International Law: Responses to the Right of Secession in Crimea” (2014) 26 Mich Intl Lawyer 4, 6 (noting the European Union’s hostility to the prospect of Scottish Secession).

${ }^{30}$ Third Committee, UNGA, $61^{\text {st }}$ Session, Summary record of the $40^{\text {th }}$ Meeting (7 November 2006), UN Doc A/C.3/61/SR.40 (2007).

${ }^{31}$ Oloka-Onyango (n 2) 196-204.

32 Third Committee (n 30) para 51.

33 ibid para 52.

${ }^{34}$ African Charter on Human and Peoples’ Rights (Nairobi, Kenya, 27 June 1981) 21 ILM 59 (1981).
} 
exercise a variant of self-determination that is compatible with the sovereignty and territorial integrity of Zaire.”35

What is most interesting here is not the specificity of the refusal to declare that Katanga was, on the facts supplied in this particular case, entitled to secede from the then Zaire. It is rather the fact that the Commission found that had Katanga shown that its oppression by the then state of Zaire had met a certain threshold, i.e. if it had shown exceptional circumstances, then it would have held it to be entitled to secede. Therein in lay the key normative import of the opinion. The similarity of this logic with the contents and thrust of the relevant provisions in the Declaration on Friendly Relations is remarkable. This soft law instrument (which has probably passed into customary international law at this point) provides inter-alia in its section on self-determination that a State is entitled to continued integral existence only as long as its government continues to represent the entire population of the State without discrimination. It is also instructive that this opinion was issued by a Commission that has among its ranks one of the leading global all-time authorities on self-determination, the late Professor Oji Umozurike. It should, however, be pointed out that since the Commission was interpreting a regional treaty, i.e. the African Charter, the decision in the Katanga case and the logic within it only applies to establish regional treaty international law and help create an equivalent principle of regional custom.

Similarly, in the Quebec Reference case (a case decided by the Supreme Court of Canada), the remedial principle was affirmed as one of the ways in which unilateral secession could lawfully occur in international law, albeit in exceptional circumstances. ${ }^{36}$ According to the court:

"In summary, the international law right to self-determination only generates, at best, a right to external self-determination [i.e. secession] ... where a people are oppressed, as for example under foreign military occupation; or where a definable group [read sub-state group] is denied meaningful access to government to pursue their political, economic, social and cultural development...Such exceptional circumstances are manifestly inapplicable to Quebec under existing conditions. 37

In reaching its decision, the court carefully canvassed international law treaties, soft law instruments, and the writings of prominent scholars, which more or less supported its logic and conclusions. Here again, the court's logic was remarkably similar to the contents and thrust of the relevant provisions in the Declaration on Friendly Relations. This is highly instructive as to the widespread and weighty influence of this Declaration (from Africa to North America). The combined effect of the Katanga and Quebec Reference cases, and of the material on which these decisions rested (especially the Declaration on Friendly Relations, is weighty indeed as one accounts for the contents of global customary international law in the area of secession. As a whole, these indicators suggest that the remedial principle of a limited and conditional entitlement to secession in exceptional circumstances is on the verge of gaining widespread acceptance.

\footnotetext{
${ }^{35}$ Katangese Peoples' Congress v. Zaire, Communication No. 75/92; reproduced in (1996) 3 Intl Human Rights Rep 136. Emphasis supplied.

${ }^{36}$ Reference Re Secession of Quebec, [1998] 2 SCR 217.

${ }^{37}$ ibid 287. Emphasis supplied.
} 
In any case, the more recent state practice related to the secession of Kosovo from Serbia lends very strong support to the conclusion that such a customary international law right has indeed emerged. Indeed, a close reading of the debates that occurred in the UN Security Council (UNSC) and the UN General Assembly (UNGA) before and after the Advisory Opinion of the International Court of Justice (ICJ) on the Unilateral Secession of Kosovo from Serbia leaves little room for reasonable doubt that the "exceptional circumstances" or "unique case” principle of secession (otherwise referred to as remedial secession) which was affirmed in the Katanga and Quebec Reference cases is now widely accepted by states. ${ }^{38}$ Indeed, in these debates a widespread and larger number of states explicitly justified Kosovo's secession on the basis that it was an "exceptional case” or "special case." 39 This widespread (if incomplete) agreement on Kosovo would mean that there is sufficiently widespread state practice coincident with opinio juris to warrant international lawyers (who are the accountants of the international law making process) to conclude that a unilateral right to secede from a parent state in exceptional cases of high levels of oppression has now emerged in global customary international law . Indeed, while speaking in the UNSC in strong opposition to the unilateral declaration of secession by Kosovo, Serbia managed to capture the mood of today's international law when it warned that:

“... [before the Kosovo affair] never in the history of the United Nations has a territory achieved statehood by seceding from a parent State that did not give its consent at the end of the process. It is up to us [the states gathered at the UN] to decide whether the time has come for that to happen for the first time in history. Serbia believes that this is not the case." 40

Given the thrust of the sentiment expressed in that and other relevant debates, and the relatively large number of states which have recognized Kosovo's secession, ${ }^{41}$ we must take it that the time had indeed come to change history, to solidify the re-making of the international law of secession - a process that, as we have seen, had begun decades before. In the circumstances, the only reasonable conclusion that can be reached is that the customary law position has changed, and that it now favors a conditional and limited right to unilateral secession in exceptional circumstances.

And this is so despite the fact that in offering its advisory opinion to the UNGA in the Kosovo case, the ICJ basically dodged the question of remedial secession (which was ironically the very basis on which Kosovo claimed an entitlement to secede from Serbia), and did not in fact say that Kosovo was so entitled. ${ }^{42}$ Rather unfortunately, Judge

\footnotetext{
${ }^{38}$ For example: UNGA, $63^{\text {rd }}$ Session, $22^{\text {nd }}$ Plenary meeting (8 October 2008), UN Doc A/63/PV.22; and UNSC, $65^{\text {th }}$ year, $6347^{\text {th }}$ meeting (3 August 2010), UN Doc S/PV.6367.

39 ibid.

${ }^{40}$ UNSC, $65^{\text {th }}$ year (n 38) 24.

${ }^{41}$ Kosovo's Ministry of Foreign Affairs reports that 96 states had recognized Kosovo's independence as at $8^{\text {th }}$ April 2015: Republic of Kosovo, Ministry of Foreign Affairs, "Countries that have recognized the Republic of Kosova" <http://www.mfa-ks.net/?page=2,33> accessed 8 April 2015. However another website reports this figure to be 110 as at the same date: "Kosovo Thanks You"

$<$ http://www.kosovothanksyou.com> accessed 8 April 2015. Kosovo's independence has thus been recognized by about half of the member states of the United Nations (UN). It is, however, unlikely to become anytime soon because it is not recognized by Russia and China.

${ }^{42}$ Accordance with international law of the unilateral declaration of independence in respect of Kosovo, Advisory Opinion, ICJ Rep 2010 (July 22) 403. Also see Robert L Howse and Ruti Teitel, "Humanity
} 
Cancade Trindade's robust, human rights-based, and deeply philosophical, defense of remedial secession in his separate opinion, including his excellent logic that "states exist for human beings and not vice-versa," cannot be taken to constitute the judgment of the ICJ in this matter. ${ }^{43}$ Nevertheless, it was a $n$ important step in the right direction.

The fact that most states in the world and most members of the UNGA or UNSC have not to date supported the secession of the Crimea from the Ukraine and its (re)union with Russia, ${ }^{44}$ does not detract at all from the argument that the weight of the state practice/opinio juris suggests that customary international law now recognizes a conditional and limited right to unilateral secession in exceptional circumstances.

The point remains that the weight of the other evidence now supports the existence on the global level of an entitlement to secede in exceptional circumstances, when there has been a high degree of state oppression of the relevant sub-state group. As such, scholars like Vidmar, who maintained as recently as 2013 that "unilateral secession is thus never a right or an entitlement under international law, not even where 'remedial arguments could plausibly be advanced," are wrong on this score. ${ }^{45}$ Among other mistakes, they tend to conflate the positions under customary and treaty international law, and equate the transgression of law with its normative content.

What remains rather unclear, though, are the criteria by which an exceptional circumstance" or a "unique case" is to be identified. Other than relying on the play of high politics to tell us the answer to this question, leading to the (overly selective) overdetermination of the question by the great powers, how are we to know when an exceptional circumstance or a unique case presents itself? And who is to decide if a case is exceptional/unique or not? Neither the Katanga case, not the Quebec Reference case is helpful in answering these more detailed, nitty-gritty questions.

And so, to reiterate, there is considerably more human rights discourse and significantly more application of normative criteria in today's international law of secession than was hitherto the case. Beginning with the adoption of the international human rights documents and congealing in the Declaration on Friendly Relations, the normative trend (however imperfect) has been to apply normative criteria to the question of the acceptability or otherwise of secession from an established state. The withholding of recognition from the defunct South African homelands (effective as they were in their existence) by almost every single state in the world in existence at the time, based on largely normative grounds, affirmed the growing turn to the "righting" of the

Bounded and Unbounded: The Regulation of External Self-Determination under International Law” (2013) 7 L and Ethics of Human Rights 155; Theodore Cristakis, “The ICJ Advisory Opinion on Kosovo: Has International Law Something to Say about Secession?” (2011) 24 Leiden J Intl L 73; Ioana Cismas, "Secession in Theory and Practice: The Case of Kosovo and Beyond" (2010) 2 Gottingen J Intl L 531; and Ralph Wilde, "Self-Determination, Secession, and Dispute Settlement after the Kosovo Advisory Opinion" (2011) 24 Leiden J Intl L 149. For a more supportive reading of the Kosovo Opinion, see also Marc Weller, "Modestly can be a Virtue: Judicial Economy in the ICJ Kosovo Opinion (2011) 24 Leiden J Intl L 127.

${ }^{43}$ Separate Opinion in the Kosovo Case, at paragraphs 14-20 and paragraph 24.

${ }^{44}$ For example: UNGA, $68^{\text {th }}$ session (1 April 2014), UN Doc A/RES/68/262; UNSC, 69 ${ }^{\text {th }}$ year, $7134^{\text {th }}$ meeting (13 March 2014), UN Doc S/PV.7134; and Simon Chesterman, “Crimean War 2.0: Ukraine and International Law” (March 2014) The Straits Times 1.

${ }^{45}$ Vidmar, Democratic Statehood (n 28) 245. 
international law of state formation and secession, ${ }^{46}$ the move toward the use of normative criteria for state emergence/creation, and the principle that "an entity will...not become a state where it would emerge in breach of certain fundamental norms of international law, in particular those of a jus cogens character [such as the anti-apartheid, anti-racism, and anti-genocide norms]." ${ }^{47}$ What the discussion about the state practice regarding the secession of Kosovo from Serbia also clearly establishes is that the converse is true as well. That is that in our own time, in today's international law of secession, a state will not also remain integral where its conduct toward one of its constituent entities constitutes a serious enough breach of certain fundamental norms of international law. This is the principle of "remedial secession" which, in my own view, has now emerged into customary international law, ${ }^{48}$ and which must also positively condition our interpretation of the relevant treaty international law provisions.

Clearly this emergent position is far more conducive to the protection of the human rights of sub-state groups around the world from oppressive political and socioeconomic conditions. It pays far greater attention to the need to their perspective and sends a stronger signal than was previously the case to parent states that if they wish to remain integral and retain the sub-state group within them, then they must not treat these groups with such a high level of oppression that the objectively verifiable social conditions thereby produced meets the threshold for trumping the territorial integrity of a state.

\section{A much greater tendency to turn to democratic political or adjudicative process} Unlike the position in the pre-UN Charter era, the international law of secession of our time is becoming significantly more constrained by both domestic and international democratic and adjudicative, process. No longer is success on the battlefield the only viable route to secession. The "infra-review" (i.e. self-assessment, opinions and indeed self-determination) of the members of the relevant sub-state group now counts (albeit only to some degree) when the legitimacy and legality of a secessionist bid is assessed by other states and by international institutions. Aside from the other evidence in support of this position, this much is crystal clear from review of the debates in the UNSC and UNGA concerning Kosovo's secession from Serbia. ${ }^{49}$ While the "peer review” of the already established states in the international community still matters a whole lot, it no longer exclusively determines whether or not a secessionist bid is considered legitimate/legal, or not, under contemporary international law. ${ }^{50}$

The emerging turn to democratic political process in the internal and international legal practice of states reinforces this conclusion. Such democratic process gleans the orientation of the bulk of opinion amongst the population of the relevant sub-state group as to the secessionist bid at issue. The recent democratic referenda in South Sudan and

\footnotetext{
${ }^{46}$ I borrow this concept of “righting from Karen Knop’s work: Karen Knop, “The Righting of Recognition: Recognition of States in Eastern Europe and the Soviet Union” (1992) Canadian Council of International Law Proceedings 36.

${ }^{47}$ Vidmar, Democratic Statehood (n 28) 61.

${ }^{48}$ For an opposing view, see ibid and Jure Vidmar, "Remedial Secession in International Law: Theory and (Lack of) Practice” (2010) 6 St. Anthony’s Intl Rev 37.

${ }^{49}$ For example: UNGA, $63^{\text {rd }}$ Session (n 38); and UNSC, $65^{\text {th }}$ year (n 38).

${ }^{50}$ ibid.
} 
Scotland, ${ }^{51}$ the inclusion of a conditional right to secession subject to a kind of democratic process in the Ethiopian Constitution, ${ }^{52}$ the conclusion of the Supreme Court of Canada that Canada is divisible according to a certain democratic process and the enactment of a Federal Canadian statute clarifying that process, ${ }^{53}$ the conduct of other similar referenda around the world, and the obvious willingness of most in the international community to honor the outcomes of such domestic democratic processes, suffice to exemplify this emerging turn. This is not to say that these are the earliest indications of the utilization around the world of democratic political process in the area of secession. The point is that the concentration and heightening to some extent of these developments in the last two decades or so signifies a trend that appears to be firming in our time. The example of the referendum in Crimea may not be helpful here as it has not been met with widespread approval around the World, largely because it was thought to have been conducted at a time that Russia - a foreign power - was in effective military control of that area. ${ }^{54}$ It should also be noted that China's so-called Anti-Secession Law seems to represent a counter current in this regard. ${ }^{55}$

Further reinforcement for the view that the contemporary international law of secession is experiencing an emerging turn to process is provided by evidence of its turn in certain cases to adjudicative review of the legality and legitimacy of particular secessionist bids. ${ }^{56}$ After the Katanga case (litigated at, and decided by, the African Commission on Human and Peoples' Rights), the Quebec Reference case (a decision of the Supreme Court of Canada), and the Advisory Opinion on the Unilateral Declaration of Independence by Kosovo (decided by the International Court of Justice or ICJ), it is no longer open to reasonable doubt that the secession of a sub-state group from an established state is a matter that is fit for adjudicative and quasi-adjudicative processes (such as in international human rights institutions, domestic courts and international courts/tribunals). The already discussed debates in the UNGA and the UNSC regarding the Kosovo secession affair, including on the propriety of referring Kosovo's unilateral declaration of independence to the ICJ, show overwhelming support in more recent state practice for this conclusion. ${ }^{57}$ Indeed, these debates even go as far as suggesting that secessionist disputes ought normally to be subjected to third party, adjudicative, review.

However, as I have long argued in another forum, triadic (i.e. third party) adjudication is far more suitable than its dyadic or bilateral/inter-party variant, for

\footnotetext{
${ }^{51}$ Obehi S Okojie, "Between Secession and Federalism: The Independence of South Sudan and the Need for a Reconsidered Nigeria” (2013) 26 Glob Bus Dev L J 415; and Angela K Bourne, "Europeanization and Secession: The Cases of Catalonia and Scotland” (2014) 13 J Ethnopolitics and Minority Language Issues 94.

${ }^{52}$ Lovise Aalen, "Ethnic Federalism and Self-Determination for Nationalities in a Semi-Authoritarian State: The Case of Ethiopia” (2006) 13 Intl J of Minority and Group Rights 243.

53 Okafor, "Entitlement” (n 2) 48, 62-64.

${ }^{54}$ William W Burke-White, “Crimea and the International Legal Order” (2014) 56 Survival: Global Politics and Strategy 65; and Chesterman (n 44).

${ }^{55}$ Letter from a Group of state allies of Taiwan to the President of the UNGA (20 July 2005), UN Doc A/59/877; Letter from the Permanent Representative of China to the UN to the President of the UNGA (25 July 2005), UN Doc A/59/879; Letter from the Permanent Representative of China to the UN to the Secretary-General of the UN (15 August 2005), UN Doc A/60/255.

${ }^{56}$ Okafor, "Entitlement” (n 2) 56-70.

${ }^{57}$ For example: UNGA, 63 ${ }^{\text {rd }}$ Session (n 38); and UNSC, $65^{\text {th }}$ year (n 38).
} 
secessionist dispute resolution. ${ }^{58}$ While some new states have emerged or could emerge through dyadic dispute resolution processes (political or adjudicative), i.e. through a process of domestic consensus-building within the parent state, ${ }^{59}$ in the highly charged, suspicion-ridden and asymmetrical power-contexts in which most secessionist disputes emerge and are maintained, a dyadic process - even one which involves adjudication by a domestic court - in which the sub-state group's fate is essentially left in the hands of an estate of the domestic realm, an organ and arm of the very parent state that the members of the usually far less powerful group have revolted against, has a far lesser chance of resolving the dispute "in a way that fosters and sustains the confidence of the parties thereto in the legitimacy of the processes involved and the outcomes that are entailed.”60 As Alec Stone Sweet has correctly noted, the triad - two contracting parties and a dispute resolver - constitutes a primal social institution," and for a good reason too. ${ }^{61}$ Against this background, the point here is that, for the reasons already offered, the need for the triadic kind of dispute resolution model is even more acute in the area of secession. For this reason, the triadic ICJ/African Commission models of secessionist dispute resolution are more readily generalizable around the world than the more dyadic Supreme Court of Canada model. This is not to say that a dyadic model of secessionist dispute resolution will in all cases lead to serious doubts among the target audience regarding the fairness and legitimacy of the judicial process. For, after all, some domestic judiciaries are more independent and respected by the local population than others. The point though is that as secession is a question that taxes to extremes the emotional strength of all sides to the dispute, ${ }^{62}$ the triadic model is to be preferred in the vast majority of cases. The cries among all-too-many Quebecois about even the highly independent and respected Supreme Court of Canada, which is constituted by a fair percentage of Quebec judges, behaving like the "leaning tower of Pisa" that only leans in one direction on matters concerning Quebec secession, are instructive in this respect. ${ }^{63}$

It is important to end this sub-section by noting that this emerging turn to democratic political and adjudicative processes is not inconsequential for the protection of the human rights of sub-state groups. To the extent that the old regime in which such processes did not play nearly as large a role contributed to the generation and augmentation of high levels of secession-related violence, the contemporary shift has a strong potential to reduce such violence. By channeling secessionist agitation to clearly more peaceable process it thereby reduces the massive violations of human rights that secessionist-related violence has historically fostered around the word. In this way will it also contribute to the fulfillment of the lofty ideals that framed the UN Charter and the attempt to construct a much more peaceful post-1945 world order.

The continuation of high levels of selectivity in the invocation of pro- or anti-secession principles

\footnotetext{
${ }^{58}$ Okafor, “Entitlement” (n 2) 56-70.

${ }^{59}$ Vidmar, Democratic Statehood (n 28) 65-77.

${ }^{60}$ Okafor, "Entitlement” (n 2) 56.

${ }^{61}$ Alec Stone Sweet, “Judicialization and the Construction of Governance” (1999) 32 Comp Political Studies 147, 148-149.

${ }^{62}$ Sujit Choudhry and Robert L Howse, "Constitutional Theory and the Quebec Secession Reference" (2000) 13 Can J L Jur 143, 145.

${ }^{63}$ Robert A Young, “A Most Politic Judgment” (1998) 10 Constit Forum 14, 15.
} 
Unfortunately, as every keen student of our global (dis)order and international law should realize, the high politics of international relations has tended to significantly affect the orientation and effect of international law. One does not need to subscribe to realist international relations theory to appreciate this. Along these lines, there has been substantial continuity in the strong tendency among states (especially the great powers) to selectively invoke pro- or anti-secession principles. ${ }^{64}$ This tendency has, thus far, not waned all that much. For example, Russia opposed Kosovo's secession from its allied state, Serbia while at the same time arguing strongly in favor of the secession of the Crimea from the Ukraine, a drama which it is widely accused of helping author. ${ }^{65}$ Russia, which has also tended to take a strong anti-secessionist posture in the past, seemed to have changed its mind with regard to South Ossetia and Abkhazia. ${ }^{66}$ And the very Western powers which authored Kosovo's secession can be heard strongly opposing a clear desire on the part of the vast majority of the ethnic Russian-dominated population in the Crimea to secede from a now Western-leaning Ukraine. ${ }^{67}$ These are but two recent examples of the ways in which high politics still manages - quite unsurprisingly - to shape state practice in this area; the very state practice that contributes to the formation of customary international law.

\section{A significantly less oppressive concept of legitimate statehood}

As a consequence of the shifts discussed in the preceding sub-sections, the concept of legitimate statehood in contemporary international law has been significantly re-defined, though not completely transformed. From one in which states were almost totally free to coercively retain even a highly oppressed sub-state group, it is in the process of being reconfigured to one in which the human rights of such groups have become an important (albeit still non-dominant) part of the discussion and calculus as to the legitimacy of the statehood of the state at issue. Thus, the prevailing concept of legitimate statehood in our time no longer automatically accepts and legitimizes socio-political power/injustice. It is no longer more or less a pro-status quo concept. The interest of established states in remaining integral, no matter how oppressive they have been to one or more of their substate groups no longer takes as much precedence as it used to over the well-being and even the every survival of the relevant oppressed peoples.

A consequently better environment for the protection of sub-state groups

The broad consequence of the shift in the normative orientation of international law and praxis that has been discussed here is that the undue disadvantage, if not repression, that has been the historic lot of all-too-many sub-state groups is being ameliorated in the result. The international law of secession now possesses a greater potential to sere as a resource in the hands of those who seek to protect vulnerable or oppressed sub-state groups from their parent states. Although most oppressed peoples will, in practice, remain unable to totally shake off their shackling to their parent state, and only a very

\footnotetext{
${ }^{64}$ Sterio (n 26).

${ }^{65}$ Theodore Christakis, "Self-Determination, Territorial Integrity and Fait Accompli in the Case of Crimea" (2015) 75 Heidelberg J Intl L (forthcoming).

${ }^{66}$ ibid.

${ }^{67}$ Christian Marxsen, “The Crimea Crisis - An International Law Perspective” (2015) 72 Heidelberg J Intl L 367.
} 
few exceptional circumstances can meet the very high threshold that has been set for entitlement to unilateral secession, the very fact that such an entitlement exists (however conditionally and exceptionally) is itself remarkable given the historically deep hostility of established states to secession. The fact remains that the repertoire of normative resources available to be deployed by such sub-state groups in their political struggles to free themselves of their oppression by a parent state has now been expanded.

\section{Tomorrow:}

The task at hand in this section is to envision the future of the international law of secession over the next half-century or so, taking into account developments in its pre1945 past and its post UN Charter-era present, and considering the trajectory that it appears to have been following. In the future of this aspect of international law, what will the treaty international law on secession look like? In what direction is the relevant customary international law likely to develop? Will the "effectiveness confers legitimacy" doctrine continue to wane, remain constant in its current character, or even re-strengthen? Will the on-going "righting" of secession continue - i.e. the increasing subjection of secessionist high politics to human rights and normative discourse and analysis? Will democratic political and/or adjudicative process play a greater, similar or lesser role than it currently does? Will excessive selectivity continue to characterize the invocation by states and civil societies alike of pro- and anti-secession principles? Will the ongoing re-definition of the concept of legitimate statehood (away from its excessively pro-status quo past) strengthen, plateau, or even wane? And will the international law of secession become more or less able to contribute to protect sub-state groups from oppressive parent states?

An analysis of the historical trajectory of international legal praxis, the general mood among states, and their actual praxis, appears to suggest that, as human rights discourse and praxis (very broadly conceived) continues its modest "conquests" atop the "high moral plateau" its now sits, ${ }^{68}$ and solidifies its grip on the imaginary of the world's peoples and their states, the relevant customary international law norms on remedial secession will solidify further over the next half century or so; albeit only in its current narrow formulation. This hardening of the emergent customary law rule will also signify an increased role for the relevant treaty law. This will occur via the solidification of the ongoing trend in the case law to interpret the existing treaty provisions on the right to self-determination (mainly the common Article 1 of the two principal human rights covenants) in line with the emergent customary international law position on remedial secession and the indisputable African regional international law favoring the same. However, this interpretive process will be most effective on the global level if it largely occurs within the auspices of the International Court of Justice.

Almost concomitantly, the waning of the impact of the effectiveness doctrine on this aspect of international law is likely to continue; though only up to a point. It will be unlikely over the next half century that international legal praxis will become so transformed in the opposite direction that the mere expression of the will of an oppressed sub-state group to secede as a result of an objectively verifiable and high enough level of oppression by their parent state, will - without more - lead to the realization of their

\footnotetext{
${ }^{68}$ I owe this term to Makau Mutua’s fecund imagination: Makau Mutua, Human Rights: A Political and Cultural Critique (University of Pennsylvania Press 2002) 40.
} 
consequent entitlement to secede under the emergent doctrine of remedial secession. As some have argued, the real life effectiveness of their secessionist bid will continue to play some role into the future in the realization of the secessionist ambition of such a sub-state group (whether this effectiveness is the result of that bid being backed by the great powers or stems from the sub-state group's military success against their parent state). Some have even gone as far as arguing that although the effective control doctrine is "unappealing at its core," there may in fact be no intelligible (complete) substitute for it. ${ }^{69}$ The point here, however, is that the extent of the role that the doctrine of effectiveness plays in this area of the law will likely diminish over the next half century or so. One important recent indication that this will come to pass is the fact that a great power such as Russia still felt the strong need to conduct a referendum in the Crimea in order to provide normative justification to the world for its hiving off of the Crimea from the Ukraine, even when it had clearly established completely effective control of that territory. ${ }^{70}$

The flip side of the coin of the waning of the effectiveness doctrine is therefore that normative legitimism is on the rise in the international law of secession, and that even more importantly - the emergent, conditional, and admittedly narrow, right of substate groups to secede in exceptional circumstances, when a high enough level of oppression by the relevant parent state occurs, is solidifying in international law, however slowly. A note of caution must however be entered at this point. This is that this process of norm solidification is extremely unlikely to result in the generation of a general prosecession norm. The emergent, narrow, and conditional entitlement to secession in exceptional cases is highly unlikely to be expanded beyond its current, highly restrictive, confines. The undisputed jus cogens status of the norm in favor of the maintenance of the territorial integrity of established states, the violence and suffering that can result from secessionist bids, and the general tendency of affected states to seek to forcibly crush such bids, combine to ensure that this will be the case well into the future. ${ }^{71}$ What is more, the heightened anti-terrorism consciousness around the world "further complicates the picture" to the point that "it seems now inconceivable that any autonomy/secessionist human rights oriented movement may escape the condemned auspices" of the terrorist. ${ }^{72}$ This will clearly reduce the appetite among sub-state groups to launch secessionist struggles, as well as discourage the majority of other states from supporting these bids.

One important consequence of the ongoing "righting” of secession is that resort to adjudicative process designed to assess whether or not the relevant sub-state group has met the threshold for remedial secession (in the mould of the disputes in the Katanga, Quebec Reference and Kosovo cases) will become more and more common in the future of international law. As importantly, resort to democratic political process in the mould of the Scotland and South Sudan affairs, will also gain even more currency. For, if a substate group could, under certain circumstances, be entitled to secede from their parent

\footnotetext{
${ }^{69}$ Brad R Roth, "Secessions, Coups and the International Rule of Law: Assessing the Decline of the Effective Control Doctrine” (2010) 11 Melbourne J Intl L 393.

${ }^{70}$ Marxsen (n 67).

${ }^{71}$ Okafor, “Entitlement” (n 2) 55; Rein Mullerson, International Law, Rights and Politics (Routledge 1994) 85.

${ }^{72}$ Upendra Baxi, The Future of Human Rights (OUP 2006) 79.
} 
state, then some kind of process to gauge their mood and discern their opinions is an irreducible minimum necessity.

As importantly, it is to such adjudicative and democratic processes that we must, of necessity, refer the important tasks - highlighted earlier on in this paper - of answering the more detailed, nitty-gritty, questions entailed by the "righting" of secession. If the international law of secession allows sub-state groups to secede from their current states only in "unique" or "exceptional circumstances," how are we to know when an exceptional circumstance or a unique case presents itself? And who is to decide if a case is exceptional/unique or not? No detailed, conclusive, a priori, formula can be offered which would meet all cases that will arise in the future of international law and relation. However, it is possible to offer certain indices or guides to such future adjudicative or democratic action. For example, in assessing a given situation to determine whether it is exceptional enough to justify remedial secession, the extent to which the parent state has committed the most heinous international crimes against the relevant sub-state group (such as genocide, war crimes, and crimes against humanity); the extent to which the relevant sub-state group has suffered consistently gross discrimination (of an economic, social and/or political nature) at the hands of the institutions of government of the parent state; and the chances of the parent state immediately ceasing and desisting from, and atoning/compensating fully for, committing such heinous crimes or gross discrimination against the relevant sub-state group, should be considered. This list is not, of course, exhaustive.

This is not to say that the deployment of such norms, processes and indicators in the future will, in practice, always lead to the secession of the relevant sub-state group. For, high levels of selectivity will very likely continue to characterize this area of international relations and law, as this is an area of the law that is as driven by high politics as any other. After all, nothing less than the continued integral existence and even survival of states (the most powerful international actors) is at stake. For example, while international law was drawn upon and invoked by all sides to the dispute over the secession of the Crimea from the Ukraine, high politics still dominated the behavior of the most relevant states, as well as much analysis of the ensuing drama. ${ }^{73}$ And even in regard to Kosovo, Ralph Wilde has correctly observed that:

"Where other sub-state groups who aspire to independence should focus their attention...is not so much on what the international law position is on the legality of declarations of independence, but rather, on their prospects of enjoying the support of at least the kind of critical mass of other states that will make their claim practically viable."74

This attests to the continuing dominance of high politics in the international law and praxis of secession, despite the slow shift to normative legitimism that is occurring. Worse still, the high politics that, as we have just seen, matters a whole lot in this area, is not as principled as it could be. It is still characterized by an excessively high level of selectivity.

Nevertheless, the weight of the ongoing shift toward normative legitimism and away from the effectiveness doctrine, however partial this may be, will ensure that the

\footnotetext{
${ }^{73}$ Marxsen (n 67).

${ }^{74}$ Ralph Wilde, "Self-Determination, Secession, and Dispute Settlement after the Kosovo Advisory Opinion” (2011) 24 Leiden J Intl L 149.
} 
concept of legitimate statehood will continue to be re-defined in the opposing direction from its generally pro-status quo, might is right, orientation over the last few centuries. The legitimacy of statehood will in the future of international law be judged according to a variety of criteria, among which will be the extent to which the established state at issue has oppressed one or more of its constituent sub-state groups. The converse would be that the legitimacy of a state would also depend more on the extent to which the relevant state has protected the rights of all its sub-state groups than is the case today. The effectiveness of established states will continue to matter much in the state legitimacy and legitimization calculus, but it will no longer matter as much as it does today.

In the result, to the extent that they are enjoyed at all, the protections enjoyed in law and fact by sub-state groups from oppressive political and socio-economic conditions within their parent states will be augmented. The more the shift in international law and praxis that has been analyzed in this paper solidifies and continues, the more the human rights of sub-state groups will enjoy both normative and real life protection.

\section{Conclusion:}

It has been argued in this paper that the international law of secession is, in general, moving steadily but slowly away from its historical tendency to automatically legitimize the status quo, however oppressive that reality may have been, and that this shift is likely to continue in the next half-century or so of the future of international law. The waning of the dominance of the doctrine that effectiveness confers legitimacy; resort to considerably more human rights discourse and its application than has hitherto been the case; and a greater tendency to turn to adjudicative or democratic political process, have all ensured that the concept of legitimate statehood in international law no longer automatically accepts and reflects socio-political power/injustice. This has in turn led to the ongoing emergence of a normative orientation within the international law of secession that holds a greater potential to contribute to the protection of all-too-often vulnerable groups from all-too-many rapacious and repressive parent states.

The overall hope, therefore, is that the international law of secession will in this way become much more reconciled to international human rights law; and that, in the result, for most of the all-too-many sub-state groups who suffer under oppressive state formations, their tomorrow will be much brighter than their today, even as their today is already much better than their yesterday.

\section{Bibliography}

Aalen L (2006) Ethnic Federalism and Self-Determination for Nationalities in a SemiAuthoritarian State: The Case of Ethiopia. Intl J of Minority and Group Rights $13: 243-261$

ACHPR (African Court of Human and Peoples’ Rights), Katangese Peoples’ Congress v. Zaire (1996), Communication No. 75/92; reproduced in Intl Human Rights Reports 3:136

African Charter on Human and Peoples’ Rights (1982) 21 ILM 59

Baxi U (2006) The Future of Human Rights. Oxford University Press, Delhi 
Bourne AK (2014) Europeanization and Secession: The Cases of Catalonia and Scotland. $\mathrm{J}$ of Ethnopolitics and Minority Language Issues 13:94-120

Brownlie I (1990) Principles of Public International Law. Clarendon Press, Oxford

Burke-White WW (2014) Crimea and the International Legal Order. Survival: Global Politics and Strategy 56:65-80

Cassese A (1995) Self-Determination of Peoples: A Reappraisal. Cambridge University Press, Cambridge

Charter of the United Nations (1945), 26 June 1945. Bevans 3:1153

Chesterman S (2014) Crimean War 2.0: Ukraine and International Law. The Straits Times 1

Choudhry S, Howse R (2000) Constitutional Theory and the Quebec Secession Reference. Can J L Juris 13:143-169

Christakis T (2015) Self-Determination, Territorial Integrity and Fait Accompli in the Case of Crimea. Heidelberg J Intl L 75 (forthcoming)

Cismas I (2010) Secession in Theory and Practice: The Case of Kosovo and Beyond. Gottingen J Intl L 2:531-588

Crawford J (1979) The Creation of States in International Law. Clarendon Press, Oxford

Cristakis T (2011) The ICJ Advisory Opinion on Kosovo: Has International Law Something to Say about Secession?. Leiden J Intl L 24:73-86

Dugard J (1992) Secession: Is the Case of Yugoslavia a Precedent for Africa. Afr J Intl Comp L 5:163-175

Fox GH (1995) Self-Determination in the Post-Cold War Era: A New Internal Focus. Mich J Intl L 16:733-791

Franck TM (1993) Post-Modern Tribalism and the Right to Secession. In: Brolman C, Lefeber R, Zieck M (eds) Peoples and Minorities in International Law. Martinus Nijhoff, Dordrecht

Franck TM (1995) Fairness in International Law and Institutions. Clarendon Press, Oxford

Guidelines on the Recognition of New States in Eastern Europe and in the Soviet Union (1991), reprinted in (1993) Eur J Intl L 9:46, annex at 72.

Hannum H (1993) Rethinking Self-Determination. Va J Intl L 34:1-70

Howse R, Teitel R (2013) Humanity Bounded and Unbounded: The Regulation of External Self-Determination under International Law. L \& Ethics of Human Rights 7:155-184

ICJ (International Court of Justice), Accordance with international law of the unilateral declaration of independence in respect of Kosovo, Advisory Opinion (22 July 2010). ICJ Rep 403

International Covenant on Civil and Political Rights (1967) ILM 6:368 
International Covenant on Economic, Social and Cultural Rights (1967) ILM 6:368

Kabir S, Edeh OJ (2014) An Evaluation of the EU and International Law: Responses to the Right of Secession in Crimea. Mich Intl Lawyer 26:4-9

Kirgis F (1994) The Degrees of Self-Determination in the United Nations Era. Am J Intl L 88:304-310

Knop K (1992) The Righting of Recognition: Recognition of States in Eastern Europe and the Soviet Union. Canadian Council of International Law Proceedings 36

Koskenniemi M (1991) The Future of Statehood. Harv Intl L J 32:392-410

Kratochwil F, Ruggie JG (1986) International Organization: A State of the Art on an Art of the State. Intl Org 40:753-775

Letter from a Group of state allies of Taiwan to the President of the UNGA (20 July 2005). UN Doc. A/59/877

Letter from the Permanent Representative of China to the UN to the President of the UNGA (25 July 2005). UN Doc. A/59/879

Letter from the Permanent Representative of China to the UN to the Secretary-General of the UN (15 August 2005). UN Doc. A/60/255

Marxsen C (2015) The Crimea Crisis - An International Law Perspective. Heidelberg J Intl L 72:367-391

McCorquodale R (1992) Self-Determination Beyond the Colonial Context and its Potential Impact on Africa. Afr J Intl Comp L 4:592-608

Mullerson R (1994) International Law, Rights and Politics. Routledge, London

Mutua M (2002) Human Rights: A Political and Cultural Critique. University of Pennsylvania Press, Philadelphia

Okafor OC (2000) Re-Defining Legitimate Statehood: International Law and State Fragmentation in Africa. Martinus Nijhoff: The Hague

Okafor OC (2002) Entitlement, Process and Legitimacy in the International Law of Secession. Intl J on Minority and Group Rights 9:41-70

Okojie OS (2013) Between Secession and Federalism: The Independence of South Sudan and the Need for a Reconsidered Nigeria. Glob Bus Dev L J 26:415-474

Oloka-Onyango J (1999) Heretical Reflections on the Right to Self-Determination: Prospects and Problems for a Democratic Global Future in the New Millennium. Am U Intl L Rev 15:151-208

Republic of Kosovo, Ministry of Foreign Affairs, "Countries that have recognized the Republic of Kosova," <http://www.mfa-ks.net/?page=2,33> accessed $8^{\text {th }}$ April 2015

Roth BR (2010) Secessions, Coups and the International Rule of Law: Assessing the Decline of the Effective Control Doctrine. Melbourne J Intl L 11:393-440 
Sterio M (2010) On the Right to External Self-Determination: 'Selfistans', Secession and the Great Powers’ Rule. Minn J Intl L 19:137-176

Stone Sweet A (1999) Judicialization and the Construction of Governance. Comp Pol Stud 32:147-184

SCC (Supreme Court of Canada), Reference Re Secession of Quebec [1998] 2 SCR 217

Tomuschat C (1993) Self-Determination in a Post-Colonial World. In: Tomuschat, C (ed) Modern Law of Self-Determination. Martinus Nijhoff, Dordrecht

Toope S (1999) Re Reference by Governor in Council Concerning Certain Questions Relating to Secession of Quebec from Canada. Am J Intl L 93:519-525

UNGA (1970) Declaration on Principles of International Law concerning Friendly Relations and Co-operation among States in accordance with the Charter of the United Nations (24 October 1970). UN Resolution A/RES/25/2625

UNGA (2007) Third Committee, General Assembly, Sixty-first session, Summary record of the $40^{\text {th }}$ Meeting, 7 November 2006 at 10 am (5 January 2007). UN Doc A/C.3/61/SR.40

UNGA (2008) Sixty-third Session, $22^{\text {nd }}$ Plenary meeting (8 October 2008). UN Doc A/63/PV.22

UNGA (2014) Sixty-eight session (1 April 2014). UN Doc A/RES/68/262

UNSC (2010) Sixty-fifth year, 6347 ${ }^{\text {th }}$ meeting (3 August 2010). UN Doc S/PV.6367

UNSC (2014) Sixty-ninth year, 7134 ${ }^{\text {th }}$ meeting (13 March 2014). UN Doc S/PV.7134

Vidmar J (2010) Remedial Secession in International Law: Theory and (Lack of) Practice. St Anthony's Intl Rev 6:37-56

Vidmar J (2013) Democratic Statehood in International Law: The Emergence of New States in Post-Cold War Practice. Hart, Oxford

Wallace-Bruce NL (1994) Claims to Statehood in International Law. Carlton Press, New York

Weller M (2011) Modestly can be a Virtue: Judicial Economy in the ICJ Kosovo Opinion. Leiden J Intl L 24:127-147

Wilde R (2011) Self-Determination, Secession, and Dispute Settlement after the Kosovo Advisory Opinion. Leiden J Intl L 24:149-154

Young C (1994) The African Colonial State in Comparative Perspective. Yale University Press, New Haven

Young RA (1998) A Most Politic Judgment. Constit Forum 10:14-18 